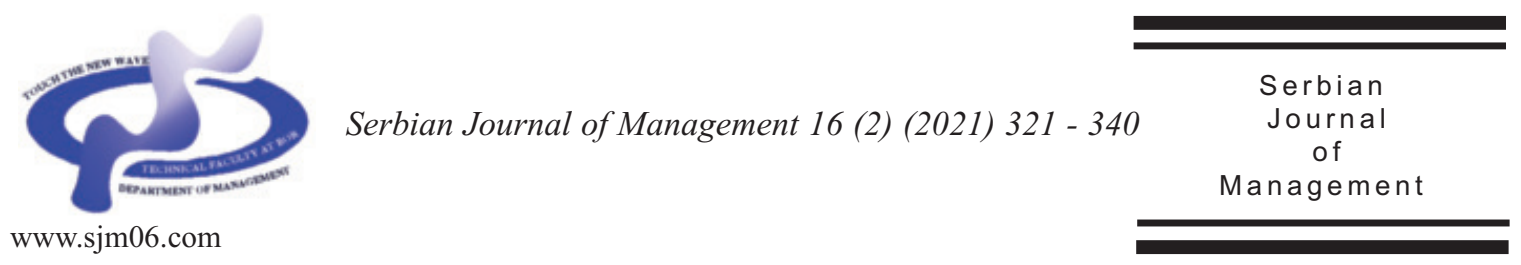

\title{
COMBINATIVE DISTANCE BASED ASSESSMENT (CODAS) FRAMEWORK USING LOGARITHMIC NORMALIZATION FOR MULTI-CRITERIA DECISION MAKING
}

\author{
Sanjib Biswas ${ }^{a}$ and Dragan Pamucar ${ }^{b *}$

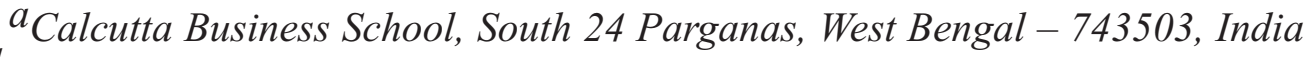

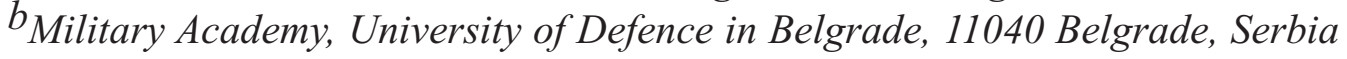

(Received 01 August 2020; accepted 01 June 2021)

\begin{abstract}
The purpose of this paper is to present an extended Combinative Distance based Assessment (CODAS) framework using logarithmic normalization (LN) scheme. LN is useful in the situations where criteria values differ significantly. This framework is used to carry out a comparative performance based ranking of the popular smartphones in India. The result obtained from this extended version of CODAS method (CODAS-LN) shows consistency with that generated by using some other established multi-criteria decision making (MCDM) approaches. The sensitivity analysis shows considerable stability in the result. Further, it is observed that CODAS-LN is free from rank reversal phenomenon and follows the transitivity property. Findings of the case study suggest that the smartphones with higher computational capability and features rank in top brackets.
\end{abstract}

Keywords: CODAS method, logarithmic normalization, smartphone ranking, sensitivity analysis

\section{INTRODUCTION}

MCDM allows the decision-makers to trade-off conflicting objectives in complex situations to select the best possible alternative among the available options. In that sense, MCDM brings multiple perspectives or dimensions (e.g., economic, social, ecological, technical, etc.) into a common platform for comparing the relative performance of available alternative courses of action for making a prudent choice (Zavadskas \& Turskis, 2011; Pamucar \& Savin, 2020). MCDM provides an easy to implement and fast decision support system that complements the cost-benefit analysis. Over the years, researchers have developed several MCDM algorithms for solving

*Corresponding author:dpamucar@gmail.com

DOI: $10.5937 /$ sjm16-27758 
various kinds of emergent issues. These algorithms or techniques differ from each other in terms of the alternatives (based on the nature of the problems), features or attributes (also known as criteria) and their weights or priorities, and computational logic (Jahan \& Edwards, 2015). The attributes or features (also known as criteria) play a central role in every MCDM framework. However, these criteria are of different types, scales, and measurement units and optimization directions such as maximization or minimization. The objective of normalization is to bring various criteria into a non-dimensional form for comparing the alternatives (Jassbi et al., 2014; Zolfani et al., 2020). Thus, the choice of appropriate normalization scheme is of paramount importance for any MCDM framework as it posits notable variations in the outcomes and subsequently impacts the decision-making (Pavličić, 2001; Chatterjee \& Chakraborty, 2014; Jahan \& Edwards, 2015; Precup et al., 2020).

The literature shows shreds of evidence of several schemes that have been formulated by the researchers for normalization. For example, some of the normalization techniques are vector normalization, linear normalization, non-monotonic normalization, Weitendorf's linear normalization (WLN) method, the JüttlerKörth normalization (JKN) method and the Peldschus non-linear normalization (NLN) method (Eftekhary et al., 2012; Zavadskas \& Turskis 2008; Zavadskas et al., 2006). In addition to these basic normalization schemes, authors have also attempted to bring in new methods. Dehghan-Manshadi et al. (2007) introduced a novel non-linear scheme for normalization, which follows the weighting factor approach and is based on a modified digital logic. In 2008, Zavadskas and his collaborator proposed a new LN (Zavadskas \& Turskis, 2008). LN is a useful transformation for normalizing a significantly skewed data which finds its wide applications in data analysis (Changyong et al., 2014). Moving further, Sarraf et al. (2013) tested the efficacy of the technique for order of preference by similarity to ideal solution (TOPSIS) method by using statistical normalization. In their research, Jahan and Edwards (2015) highlighted many normalization methods. In this context, one question has been alluring the researchers: which one is the best normalization scheme? While there is no consensus, several researchers have tried to figure out the impact of change in the normalization approach on the final result obtained by using an MCDM technique. For instance, Çelen (2014) applied the TOPSIS method for comparing the financial performance of selected Turkish banks, wherein the author considered four normalization techniques. The author observed that vector normalization gives better results, while max-min and max methods are close alternatives. For the problem of industrial robot selection using a weighted aggregated sum product assessment method (WASPAS) framework, Mathew et al. (2017) found linear normalization (max-min) as the best normalization scheme. In this regard, Vafaei et al. (2018) used six normalization methods for the TOPSIS framework. However, none of these works used LN as a normalization scheme. Kosareva et al. (2018) mentioned that the linear min-max method performs comparatively better than its counterparts, but LN is particularly useful than the others in some specific cases. In tune with the work of Kosareva et al. (2018) and Zolfani et al. (2020) used LN as a normalization scheme 
for TOPSIS and VIKOR (Vise Kriterijumska Optimizacija Kompromisno Resenje) algorithms as they found the usefulness of LN in the situations where criteria values differ significantly.

In this context, this work uses $\mathrm{LN}$ as a normalization scheme for applying a popular distance-based MCDM algorithm, such as CODAS, in solving the smartphone selection problem. This work contributes to the growing literature by providing an alternative approach for CODAS using LN. With the limited search it may be concluded that LN has not been used for the CODAS method. In fact, in the literature, a rare use of LN is observed. Given the relevance of the problem of smartphone selection, it is found that the CODAS-LN framework is useful as the criteria for selecting a smartphone given a price bracket (suitable for the middleincome group) differ significantly from each other's in terms of nature, values, and measurement units.

The rest of this paper is organized as follows. In the next section (section 2), the proposed framework is elaborated. In section 3 , the problem considered here is discussed. Section 4 exhibits the results and includes a discussion on the findings. Finally, section 5 concludes the paper and highlights some of the future scopes.

\section{PROPOSED FRAMEWORK}

The CODAS method considers the relative importance of separating each possible solution from the positive ideal or optimistic, and negative ideal or pessimistic points. The fundamental philosophy of the CODAS method considers a combination of two distance measures, such as Euclidean (primary measure related to $1^{2}$-norm indifference space) and Taxicab (secondary measure related to $1^{1}$-norm indifference space) for comparing the alternatives (Ghorabaee et al., 2016). A threshold value is used to combine the distance measures mentioned earlier. The decision rule is dependent on the distance from the extreme negative solution (the higher is, the better). Since its introduction the CODAS framework has been used considerably by several researchers in various domains like supplier selection (Ghorabaee et al., 2017), maintenance management (Panchal et al., 2017), organizational performance assessment (Badi et al., 2018a), location selection problem (Badi et al., 2018b; Bolturk \& Kahraman, 2018), comparison of energy storage technologies (Ren, 2018), personnel selection (Tuş \& Adalı, 2018; Yeni \& Özçelik, 2019), renewable energy selection (Boltürk \& Karaşan, 2018), investment decision-making (Seker, 2019), material selection (Maghsoodi et al., 2019), evaluation of banking performance (Laha \& Biswas, 2019), and strategic decisionmaking for financial management (Despic et al., 2019; Zhou et al., 2020).

There has been a gradual extension of the original framework. For example, Ghorabaee et al. (2017) extended the CODAS framework by incorporating the fuzzy logic theory. Panchal et al. (2017) used a combined fuzzy analytic hierarchy process (AHP) and CODAS framework in a group decision-making setup. Ren (2018) applied an integrated interval AHP and intuitionistic fuzzy CODAS framework to contribute to the state of the art. Bolturk and Kahraman (2018) further extended the work by using the interval-Valued Intuitionistic Fuzzy logic. Moving further, Boltürk and Karaşan (2018) introduced the neutrosophic fuzzy logic-based CODAS framework. The work 
of Yeni and Özçelik (2019) reported the use of interval-valued Atanassov intuitionistic fuzzy CODAS for group decision-making purposes. Adding to the growing strand of literature, Ijadi Maghsoodi et al. (2019) presented a framework of step-wise weight assessment ratio analysis (SWARA) and CODAS, which considers target based attributes. As a further development, Zhou et al. (2020) formulated a linguistic Pythagorean fuzzy (LPF) based CODAS method. However, despite these gradual and consistent extension works, it is noticed that none have used LN. Instead, the researchers mostly relied on min-max and max type of normalization.

In this paper, the CODAS algorithm is used for the smartphone selection problem in which the fundamental steps are unchanged except the normalization scheme. $\mathrm{LN}$ is used as an alternative approach to examine the performance of the CODAS method.

2.1. CODAS method with logarithmic normalization (CODAS-LN)

The computational steps are described below.

Step 1: Construction of the decisionmatrix (DM) $X=\left[x_{i j}\right]_{m \times n}$ where, $m$ is the number of alternatives and $n$ is the number of criteria.

Step 2: Normalization

Instead of the linear normalization used in the original CODAS algorithm in this paper LN is used as proposed by Zavadskas and Turskis (2008). The authors observed more consistent result while using LN when the criteria values differ significantly. The work of Zolfani et al. (2020) reflected the observations made by Zavadskas and Turskis
(2008).

Suppose, $R=\left[r_{i j}\right]_{m \times n}$ is the normalized decision matrix. Then, $r_{i j}$ is calculated as follows.

$r_{i j}=\frac{\ln \left(x_{i j}\right)}{\ln \left(\prod_{i}^{m} x_{i j}\right)}$ When $j \in j^{+}$

$r_{i j}=\frac{1-\frac{\ln \left(x_{i j}\right)}{\ln \left(\prod_{i}^{m} x_{i j}\right)}}{m-1}$ When $j \in j^{-}$

Note that the sum of the normalized values for each criterion is zero.

Step 3: Derive the weighted normalized decision matrix

Weighted normalized decision matrix is given by $R^{*}=\left[r^{*}{ }_{i j}\right]_{m \times n}$ where the values are given by

$r_{i j}^{*}=w_{j} r_{i j}$; where $w_{j}$ denotes the weight of the $j$ th criterion.

$\left(\sum_{j=1}^{n} w_{j}=1\right)$

Step 4: Find out the negative ideal or most pessimistic solution.

$$
\begin{aligned}
& S^{-}=\left[s_{j}^{-}\right]_{1 x n} \\
& s_{j}^{-}=\min _{i} r_{i j}^{*}
\end{aligned}
$$

Step 5: Measure of separation from the negative ideal solution 
As stated earlier, CODAS method uses two distance measures such as Euclidean $\left(\mathrm{E}_{\mathrm{i}}\right)$ and Taxicab $\left(\mathrm{T}_{\mathrm{i}}\right)$ for calculating the distances of the alternatives from the negative ideal points. Accordingly, the separations are calculated as

$$
\begin{aligned}
& E_{i}=\sqrt{\sum_{j=1}^{n}\left(r_{i j}^{*}-s_{j}^{-}\right)^{2}} \\
& T_{i}=\sum_{j=1}^{n}\left|r_{i j}^{*}-s_{j}^{-}\right|
\end{aligned}
$$

Step 6: Formation of relative assessment matrix $R_{a}=\left[h_{i k}\right]_{m \times m}$ where

$$
h_{i k}=\left(E_{i}-E_{k}\right)+\left(\psi\left(E_{i}-E_{k}\right) \times\left(T_{i}-T_{k}\right)\right)
$$

Where, $\mathrm{k}=1,2, \ldots \mathrm{m} ; \psi$ denotes a threshold function representing the equality of the Euclidean distances of two alternatives as

$\psi(d)=1$, if $[d] \geq \tau ; 0$, otherwise

$d$ is the difference between Euclidean distances of the two alternatives and $\tau$ is a threshold parameter which determines the use of distance measure $(\tau=0.02$ as suggested by Ghorabaee et al., (2016).

Step 7: Calculation of assessment score $\left(\mathrm{H}_{\mathrm{i}}\right)$

$H_{i}=\sum_{k=1}^{m} h_{i k}$

Decision rule: The alternative with higher $H_{i}$ value is ranked first than others.
In order to calculate the criteria weights, the entropy method is used which is described in the subsequent sub-section.

\subsection{Entropy method}

The concept of the entropy method was proposed in information theory (Shannon, 1948). Over the years, this method has found its application in many research problems pertaining to various disciplines ( $\mathrm{Li}$ et al., 2011; Ghosh \& Biswas, 2016; Karmakar et al., 2018; Biswas et al., 2019; Gupta et al., 2019). This method suggests that the higher value of entropy for a particular criterion signifies a greater amount information given by it. The procedural steps (Zou et al., 2006) are given below.

Step 1: Formation of normalization matrix

The normalization matrix is represented as $(R)_{m \times n}$ where, the elements $r_{i j}$ are given by:

$r_{i j}=\frac{\left(x_{i j}-x_{j \min }\right)}{\left(x_{j \max }-x_{j \min }\right)}$

(When the criterion is having positive effect direction)

$r_{i j}=\frac{\left(x_{j \max }-x_{i j}\right)}{\left(x_{j \max }-x_{j \min }\right)}$

(When the criterion is having positive effect direction)

Step 2: Calculation of entropy values

The entropy value for $i^{\text {th }}$ alternative for $j^{\text {th }}$ criterion is given by: 
$H_{j}=-k \sum_{i=1}^{m} f_{i j} \ln \left(f_{i j}\right)$

Where,

$k=1 / \ln (m)$

$f_{i j}=\frac{r_{i j}}{\sum_{i=1}^{m} r_{i j}}$

In this context, Zou et al., (2006) mentioned that if $f_{i j}=0$ then $f_{i j} \ln \left(f_{i j}\right)=0$

Step 3: Calculation of criteria weight

The weight for each criterion is given by

$w_{j}=\frac{1-H_{j}}{n-\sum_{j=1}^{n} H_{j}}$

\section{ILLUSTRATIVE CASE STUDY: SMARTPHONE SELECTION}

In this paper, the proposed framework of CODAS-LN is used for the smartphone selection problem. With the extensive developments in information and communication technology (ICT), post2010, the world has witnessed a massive increase in the number of smartphone users. Over the years, the average price for purchasing smartphones has also come down significantly. Besides, the cost of accessing the internet has also become within reach of common people. Moreover, there have been an increased number of applications wherein smartphones are used. As a result of that, alongside the old brands like Apple, Nokia, Samsung, and Motorola, some late entrants like Xiaomi, Realme, Vivo, and Oppo have also attracted a notable number of customers able to hold a considerable amount of the total market share. As we move through an age known as Industry 4.0, the competition is getting intensified day by day, and brands are competing mainly on two aspects, such as price and features or applications. Hence, many users are curious about which brand/model to select for purchasing a smartphone for quite an apparent reason. Since the buying intension, level of use, technical awareness, and purchasing capability vary from buyers to buyers, the selection of smartphones depends on multiple criteria or attributes. In other words, smartphone selection is a typical problem for MCDM.

Many researchers have tried to solve the smartphone selection problem using various MCDM algorithms. For example, $\mathrm{Hu}$ et al. (2014) used a combined framework of DANP (DEMATEL-based ANP) and VIKOR. Yildiz and Ergul (2015) used ANP along with generalized Choquet integral (GCI). The work of Büyüközkan and Güleryüz (2016) applied intuitionistic fuzzy TOPSIS. Rani et al. (2019) further added to the literature by using an interval-valued intuitionistic fuzzy TOPSIS algorithm to compare smartphones. Saqlain et al. (2020) extended the work using the TOPSIS strategy in the neutrosophic fuzzy environment.

The next question is what the parameters or criteria for comparing the smartphones are? In this regard, Hu et al. (2014) focused on value creation. The authors compared smartphones in three dimensions: customer equity, product function, and convenience of use. Yildiz and Ergul (2015) and Saqlain et al. (2020) emphasized technical features and cost. Büyüközkan and Güleryüz (2016) considered brand image, service, cost, and 
technical features. In addition to technical features, Rani et al. (2019) also considered internet connectivity as a criterion. However, Kim et al. (2020) applied a preferential relation model to discriminate smartphones based on attributes and brand loyalty. The following table (see table 1) exhibits a comparative analysis of some recent smartphone selection work.

Table 2 describes the criteria considered in this paper. In this paper, the technical features and customer satisfaction measured by using a proxy variable called average rating are considered. As it is seen from table 1 that the criteria used in this study are in tune with past work.

A set of 25 popular smartphone models of different brands like Samsung, Redmi
(Xiaomi), Oppo, Honor, Lava, Vivo, Huawei, and Poco are selected. The price range of maximum INR 25000 is considered in the sense that customers belonging to midincome groups can afford to buy these models. Those models with wide popularity (i.e., average customer rating of 4-star and above) on acclaimed e-commerce platforms like Amazon are considered. The relevant information is collected mainly from publicly available data sources like company websites and e-commerce sites. The aim is to compare these 25 models using the proposed Entropy- CODAS-LN framework to suggest possible best option to buy. Table 3 shows the performance values of those models based on the criteria considered (see table 2).

Table 1. Comparison of some recent work

\begin{tabular}{|c|c|c|c|c|c|c|c|c|c|}
\hline & $\begin{array}{c}\text { Işıklar and } \\
\text { Büyüközkan } \\
(2007)\end{array}$ & $\begin{array}{l}\text { Hu et al. } \\
\text { (2014) }\end{array}$ & $\begin{array}{l}\text { Yildiz and } \\
\text { Ergul } \\
(2015)\end{array}$ & $\begin{array}{c}\text { Büyüközkan } \\
\text { and Güleryüz } \\
(2016)\end{array}$ & $\begin{array}{l}\text { Aggarwal } \\
\text { et al. } \\
\text { (2018) }\end{array}$ & $\begin{array}{l}\text { Irvanizam } \\
\text { et al. } \\
\text { (2018) }\end{array}$ & $\begin{array}{l}\text { Rani et } \\
\text { al. } \\
(2019)\end{array}$ & $\begin{array}{l}\text { Saqlain } \\
\text { et al. } \\
(2020)\end{array}$ & $\begin{array}{l}\text { Our } \\
\text { study }\end{array}$ \\
\hline \multicolumn{10}{|l|}{ Criteria } \\
\hline Customer equity & & $\sqrt{ }$ & & & & & & & \\
\hline Brand choice & $\sqrt{ }$ & & & $\sqrt{ }$ & & & & $\sqrt{ }$ & \\
\hline Prestige/Esteem value & & & & $\sqrt{ }$ & & & & & \\
\hline Aesthetics & $\sqrt{ }$ & & & $\sqrt{ }$ & & & & & \\
\hline Memory (RAM, Internal Memory) & $\sqrt{ }$ & $\sqrt{ }$ & $\sqrt{ }$ & $\sqrt{ }$ & $\sqrt{ }$ & $\sqrt{ }$ & $\sqrt{ }$ & $\sqrt{ }$ & $\sqrt{ }$ \\
\hline Processor & & $\sqrt{ }$ & $\sqrt{ }$ & $\sqrt{ }$ & $\sqrt{ }$ & & & $\sqrt{ }$ & $\sqrt{ }$ \\
\hline Touch panel & & $\sqrt{ }$ & & & & & & & \\
\hline Operating system & & $\sqrt{ }$ & $\sqrt{ }$ & $\sqrt{ }$ & & & $\sqrt{ }$ & & \\
\hline Dimensions (thickness, screen size etc.) & $\sqrt{ }$ & & $\sqrt{ }$ & $\sqrt{ }$ & $\sqrt{ }$ & $\sqrt{ }$ & & $\sqrt{ }$ & $\sqrt{ }$ \\
\hline Main camera (MP) & & & $\sqrt{ }$ & $\sqrt{ }$ & $\sqrt{ }$ & $\sqrt{ }$ & & $\sqrt{ }$ & $\sqrt{ }$ \\
\hline Front camera & & & & & & $\sqrt{ }$ & & & $\sqrt{ }$ \\
\hline Picture quality (PPI) & & & $\sqrt{ }$ & & & & & & $\sqrt{ }$ \\
\hline Weight & & & $\sqrt{ }$ & & $\sqrt{ }$ & & & & $\sqrt{ }$ \\
\hline Battery strength & & & $\sqrt{ }$ & $\sqrt{ }$ & $\sqrt{ }$ & $\sqrt{ }$ & $\sqrt{ }$ & & $\sqrt{ }$ \\
\hline Talk time & $\sqrt{ }$ & & $\sqrt{ }$ & & & & & & \\
\hline Standby time & $\sqrt{ }$ & & $\sqrt{ }$ & & & & & & \\
\hline Durability & & & & $\sqrt{ }$ & & & & & \\
\hline Network & & & & $\sqrt{ }$ & & & $\sqrt{ }$ & & \\
\hline Applications/Features & $\sqrt{ }$ & $\sqrt{ }$ & & $\sqrt{ }$ & & & & & \\
\hline Safety, Security and Privacy & $\sqrt{ }$ & & & $\sqrt{ }$ & & & & & \\
\hline Changeable parts & $\sqrt{ }$ & & & $\sqrt{ }$ & & & & & \\
\hline Price & $\sqrt{ }$ & & $\sqrt{ }$ & & $\sqrt{ }$ & $\sqrt{ }$ & $\sqrt{ }$ & $\sqrt{ }$ & $\sqrt{ }$ \\
\hline \multicolumn{10}{|l|}{ Average customer rating } \\
\hline Methodology (MCDM Framework) & & & & & & & & & \\
\hline MCDM with crisp values & $\sqrt{ }$ & $\sqrt{ }$ & $\sqrt{ }$ & & $\sqrt{ }$ & & & & $\sqrt{ }$ \\
\hline Fuzzy MCDM & & & & $\sqrt{ }$ & & $\sqrt{ }$ & $\sqrt{ }$ & $\sqrt{ }$ & \\
\hline DEMATEL & & $\sqrt{ }$ & & & & & & & \\
\hline ANP & & $\sqrt{ }$ & $\sqrt{ }$ & & & & & & \\
\hline AHP & $\sqrt{ }$ & & & & & & & & \\
\hline VIKOR & & $\sqrt{ }$ & & & & & & & \\
\hline TOPSIS & $\sqrt{ }$ & & & $\sqrt{ }$ & & & $\sqrt{ }$ & $\sqrt{ }$ & \\
\hline EDAS & & & & & $\sqrt{ }$ & & & & \\
\hline TODIM & & & & & & $\sqrt{ }$ & & & \\
\hline CODAS & & & & & & & & & $\sqrt{ }$ \\
\hline Min-max normalization & & $\sqrt{ }$ & $\sqrt{ }$ & & $\sqrt{ }$ & $\sqrt{ }$ & & & \\
\hline Vector normalization & $\sqrt{ }$ & & & $\sqrt{ }$ & & & $\sqrt{ }$ & $\sqrt{ }$ & \\
\hline Logarithmic normalization & & & & & & & & & $\sqrt{ }$ \\
\hline
\end{tabular}


Table 2. Criteria Description

\begin{tabular}{llll}
\hline Criteria & Code & Effect Direction & UOM \\
\hline Screen Size & C1 & $(+)$ & Inch \\
Processor Speed & C2 & $(+)$ & GHz \\
RAM & C3 & $(+)$ & GB \\
Internal Memory & C4 & $(+)$ & GB \\
Battery Life & C5 & $(+)$ & mAH \\
Camera Quality (front) & C6 & $(+)$ & MP \\
Camera Quality (Rare) & C7 & $(+)$ & MP \\
Picture Quality & C8 & $(+)$ & PPI \\
Avg. Customer Review & C9 & $(+)$ & Star \\
Weight & C10 & $(-)$ & gm \\
Price & C11 & $(-)$ & INR \\
\hline
\end{tabular}

Table 3. Performance values (Decision matrix)

\begin{tabular}{|c|c|c|c|c|c|c|c|c|c|c|c|}
\hline \multirow[t]{2}{*}{ Criteria } & $(+)$ & $(+)$ & $(+)$ & $(+)$ & $(+)$ & $(+)$ & $(+)$ & $(+)$ & $(+)$ & $(-)$ & $(-)$ \\
\hline & C1 & $\mathrm{C2}$ & $\mathrm{C3}$ & C4 & C5 & C6 & C7 & C8 & C9 & $\mathrm{C10}$ & C11 \\
\hline \multicolumn{12}{|l|}{ Models } \\
\hline M1 & 6.40 & 2.30 & 6 & 128 & 6000 & 20 & 48 & 403 & 4.5 & 188 & 16499 \\
\hline M2 & 6.35 & 2.00 & 6 & 64 & 5000 & 8 & 13 & 268 & 4.4 & 191 & 12990 \\
\hline M3 & 6.30 & 2.00 & 6 & 128 & 4000 & 13 & 48 & 409 & 4.4 & 191 & 14999 \\
\hline M4 & 6.53 & 2.05 & 8 & 128 & 4500 & 20 & 64 & 409 & 4.3 & 200 & 18999 \\
\hline M5 & 6.50 & 2.10 & 6 & 128 & 4020 & 16 & 48 & 394 & 4.3 & 186 & 22999 \\
\hline M6 & 6.40 & 2.30 & 8 & 128 & 6000 & 32 & 64 & 411 & 4.3 & 191 & 19499 \\
\hline M7 & 6.53 & 2.00 & 6 & 64 & 5000 & 16 & 16 & 395 & 4.4 & 193 & 12990 \\
\hline M8 & 6.35 & 2.00 & 4 & 64 & 5000 & 16 & 13 & 268 & 4.3 & 191 & 12999 \\
\hline M9 & 6.40 & 2.30 & 6 & 128 & 6000 & 16 & 48 & 403 & 4.3 & 188 & 16999 \\
\hline M10 & 6.50 & 2.00 & 4 & 64 & 5000 & 8 & 12 & 270 & 4.1 & 195 & 13999 \\
\hline M11 & 6.35 & 2.00 & 4 & 32 & 5000 & 8 & 13 & 268 & 4.2 & 191 & 14990 \\
\hline M12 & 6.67 & 2.30 & 4 & 64 & 5020 & 16 & 48 & 400 & 4.2 & 209 & 13999 \\
\hline M13 & 6.53 & 2.00 & 4 & 128 & 5000 & 16 & 16 & 395 & 4.1 & 193 & 14990 \\
\hline M14 & 6.50 & 2.00 & 6 & 128 & 5000 & 16 & 12 & 405 & 3.7 & 192 & 16990 \\
\hline M15 & 6.26 & 2.00 & 3 & 64 & 3500 & 13 & 16 & 269 & 3.8 & 172 & 13490 \\
\hline M16 & 6.53 & 2.20 & 8 & 128 & 3765 & 16 & 48 & 394 & 4.5 & 191 & 20999 \\
\hline M17 & 6.18 & 2.80 & 8 & 256 & 4000 & 20 & 12 & 403 & 4.3 & 181 & 18999 \\
\hline M18 & 6.40 & 2.10 & 8 & 128 & 4000 & 16 & 48 & 408 & 4.1 & 172 & 18990 \\
\hline M19 & 6.67 & 2.30 & 8 & 128 & 5020 & 32 & 64 & 395 & 4.5 & 209 & 16999 \\
\hline M20 & 6.59 & 2.20 & 4 & 128 & 4000 & 16 & 16 & 391 & 4.2 & 195 & 15489 \\
\hline M21 & 6.22 & 2.00 & 3 & 32 & 3260 & 8 & 13 & 270 & 4.1 & 159 & 9999 \\
\hline M22 & 5.84 & 2.36 & 4 & 128 & 3000 & 16 & 13 & 432 & 4.0 & 154 & 16490 \\
\hline M23 & 6.38 & 2.00 & 6 & 128 & 4500 & 32 & 16 & 404 & 4.3 & 177 & 19990 \\
\hline M24 & 6.22 & 1.95 & 4 & 64 & 4030 & 20 & 13 & 270 & 4.2 & 163 & 15890 \\
\hline M25 & 6.67 & 2.20 & 8 & 256 & 4500 & 20 & 64 & 395 & 4.5 & 208 & 21499 \\
\hline
\end{tabular}




\section{RESULTS AND DISCUSSION}

In this section, the results obtained from step by step data analysis by using the proposed framework is presented. Table 4 presents the criteria weights as calculated by using the entropy method (Eq. 11-16).

Next, these criteria weights are used to proceed for comparative analysis of the models selected. Table 5 shows the relative ranking of the models as obtained by using the proposed CODAS-LN framework.

It is seen from table 6 that M6, M19, and M25 secure the first three positions. If we further probe into their specifications, it reveals that these models offer higher processor speed, standard battery backup, larger capacities for RAM, and better display quality at considerable prices compared to the models belonging to the bottom performer group, i.e., M10, M11 and M25. Further, all these models are next-generation

Table 4. Criteria weights

\begin{tabular}{|c|c|c|c|c|c|c|c|c|c|c|c|}
\hline \multirow{2}{*}{ Criteria } & $(+)$ & $(+)$ & $(+)$ & $(+)$ & $(+)$ & $(+)$ & $(+)$ & $(+)$ & $(+)$ & $(-)$ & $(-)$ \\
\hline & C1 & $\mathrm{C2}$ & $\mathbf{C 3}$ & $\mathrm{C4}$ & C5 & C6 & C7 & C8 & C9 & C10 & C11 \\
\hline \multicolumn{12}{|l|}{ Values } \\
\hline $\mathbf{H j}$ & 0.97846 & 0.86582 & 0.92281 & 0.92526 & 0.95317 & 0.91006 & 0.80151 & 0.90197 & 0.97086 & 0.92785 & 0.95753 \\
\hline $\mathbf{w j}$ & 0.0243 & 0.1517 & 0.0873 & 0.0845 & 0.0529 & 0.1017 & 0.2244 & 0.1108 & 0.0329 & 0.0816 & 0.0480 \\
\hline
\end{tabular}

Table 5. Ranking result (CODAS-LN)

\begin{tabular}{cccccc}
\hline Model & Hi & Rank & Model & Hi & Rank \\
\hline M1 & 0.037842306 & 6 & M14 & -0.026923459 & 15 \\
M2 & -0.039548684 & 20 & M15 & -0.048606918 & 22 \\
M3 & 0.029404654 & 10 & M16 & 0.039040994 & 5 \\
M4 & 0.056006156 & 4 & M17 & 0.023678394 & 12 \\
M5 & 0.031784173 & 9 & M18 & 0.037418954 & 7 \\
M6 & 0.064831842 & 1 & M19 & 0.064821897 & 2 \\
M7 & -0.027691733 & 16 & M20 & -0.028000699 & 17 \\
M8 & -0.045343094 & 21 & M21 & -0.070865273 & 25 \\
M9 & 0.035722806 & 8 & M22 & -0.023167856 & 14 \\
M10 & -0.057791004 & 23 & M23 & -0.007852396 & 13 \\
M11 & -0.061136586 & 24 & M24 & -0.039327293 & 19 \\
M12 & 0.028732162 & 11 & M25 & 0.060751762 & 3 \\
M13 & -0.033781106 & 18 & & & \\
\hline
\end{tabular}

Table 6. Comparison of ranking results

\begin{tabular}{|c|c|c|c|c|c|c|c|c|c|c|c|}
\hline Model & $\begin{array}{c}\text { Rank } \\
\text { (CODAS_LN) }\end{array}$ & $\begin{array}{c}\text { Rank } \\
\text { (TOPSIS_LN) }\end{array}$ & $\begin{array}{c}\text { Rank } \\
\text { (CODAS) }\end{array}$ & $\begin{array}{c}\text { Rank } \\
\text { (TOPSIS) }\end{array}$ & $\begin{array}{l}\text { Rank } \\
\text { (EDAS) }\end{array}$ & Model & $\begin{array}{c}\text { Rank } \\
\text { (CODAS_LN) }\end{array}$ & $\begin{array}{c}\text { Rank } \\
\text { (TOPSIS_LN) }\end{array}$ & $\begin{array}{c}\text { Rank } \\
\text { (CODAS) }\end{array}$ & $\begin{array}{c}\text { Rank } \\
\text { (TOPSIS) }\end{array}$ & $\begin{array}{c}\text { Rank } \\
\text { (EDAS) }\end{array}$ \\
\hline M1 & 6 & 4 & 5 & 5 & 5 & M14 & 15 & 17 & 15 & 15 & 17 \\
\hline M2 & 20 & 20 & 20 & 21 & 21 & M15 & 22 & 22 & 22 & 22 & 22 \\
\hline M3 & 10 & 11 & 10 & 10 & 10 & M16 & 5 & 7 & 8 & 8 & 8 \\
\hline M4 & 4 & 6 & 4 & 4 & 4 & M17 & 12 & 12 & 12 & 12 & 12 \\
\hline M5 & 9 & 9 & 9 & 9 & 9 & M18 & 7 & 8 & 6 & 6 & 7 \\
\hline M6 & 1 & 1 & 1 & 2 & 1 & M19 & 2 & 2 & 2 & 3 & 2 \\
\hline M7 & 16 & 16 & 16 & 18 & 18 & M20 & 17 & 15 & 18 & 17 & 14 \\
\hline M8 & 21 & 21 & 21 & 20 & 20 & M21 & 25 & 25 & 23 & 24 & 25 \\
\hline M9 & 8 & 5 & 7 & 7 & 6 & M22 & 14 & 14 & 14 & 14 & 16 \\
\hline M10 & 23 & 23 & 24 & 23 & 23 & M23 & 13 & 13 & 13 & 13 & 13 \\
\hline M11 & 24 & 24 & 25 & 25 & 24 & M24 & 19 & 19 & 19 & 19 & 19 \\
\hline M12 & 11 & 10 & 11 & 11 & 11 & M25 & 3 & 3 & 3 & 1 & 3 \\
\hline M13 & 18 & 18 & 17 & 16 & 15 & & & & & & \\
\hline
\end{tabular}


smartphones, which are launched very recently. This finding indicates the buyers' inclination towards computational power and storage capacities to support high end and exhaustive applications.

\subsection{Validation}

Next, validation of the results obtained by using the CODAS-LN framework is examined. The results of CODAS-LN based analysis are compared with that of using other commonly used distance-based MCDM algorithms to check whether there are significant deviations in the comparative rankings of the smartphones under comparison (Biswas \& Pamucar, 2020). For this purpose, the frameworks like TOPSIS (Hwang \& Yoon, 1981), EDAS (Ghorabaee et al., 2015) and original form of CODAS (Ghorabaee et al., 2016) are applied for ranking the same group of smartphones. In addition, the calculation of TOPSIS based on LN (TOPSIS-LN) is also carried out. Table 6 highlights the comparison of ranking results. It is evident from the above table that ranking is quite consistent in nature. The results are compared further statistically by using Spearman's rank correlation and
Kendall's correlation test (see table 7). It is observed that the ranking result obtained by using CODAS-LN method is highly consistent with that of using the established frameworks.

Moving further the possibility of the rank reversal phenomenon is checked in case of CODAS-LN framework. One of the major drawbacks that the MCDM methods are suffered from is rank reversal phenomenon (RRP). In many cases it is found that the ranking orders as obtained by using a particular MCDM algorithm gets changed as a consequence of addition or deletion of a particular alternative (de Farias Aires \& Ferreira, 2019). In the past several researchers have worked on this issue for examining the effectiveness for several MCDM methods such as TOPSIS (Wang \& Luo, 2009; Chatterjee \& Stevic, 2019), ELECTRE (Wang \& Triantaphyllou, 2008), PROMETHEE (Macharis et al., 2004), ANP (Kong et al., 2016), GRA (Huszak \& Imre, 2010), DEA (Soltanifar \& Shahghobadi, 2014; Hassanpour \& Pamucar, 2019) and the list continues.

Although, the true reason for occurrence of RRP is not fully established (MousaviNasab \& Sotoudeh-Anvari, 2018),

Table 7. Consistency test I

\begin{tabular}{|c|c|c|c|c|c|c|}
\hline & & $\begin{array}{l}\text { Rank_- } \\
\text { CODAS_LN }\end{array}$ & $\begin{array}{l}\text { Rank_} \\
\text { CODAS }\end{array}$ & $\begin{array}{l}\text { Rank_} \\
\text { TOPSIS }\end{array}$ & $\begin{array}{l}\text { Rank_}_{-} \\
\text {EDAS }\end{array}$ & $\begin{array}{l}\text { Rank_} \\
\text { TOPSIS_LN }\end{array}$ \\
\hline \multirow{5}{*}{ Kendall's tau } & Rank_CODAS_LN & 1 & & & & \\
\hline & Rank_CODAS & $.960 * *$ & 1 & & & \\
\hline & Rank_TOPSIS & $.933 * *$ & $.960 * *$ & 1 & & \\
\hline & Rank_EDAS & $.927 * *$ & $.927 * *$ & $.940 * *$ & 1 & \\
\hline & Rank_TOPSIS_LN & $.940 * *$ & $.927 * *$ & $.913 * *$ & $.933 * *$ & 1 \\
\hline \multirow{5}{*}{ Spearman's rho } & Rank_CODAS_LN & 1 & & & & \\
\hline & Rank_CODAS & $.992 * *$ & 1 & & & \\
\hline & Rank_TOPSIS & $.988 * *$ & $.994 * *$ & 1 & & \\
\hline & Rank_EDAS & $.982 * *$ & $.984 * *$ & $.989 * *$ & 1 & \\
\hline & Rank_TOPSIS_LN & $.988 * *$ & $.986 * *$ & $.984 * *$ & $.988 * *$ & 1 \\
\hline
\end{tabular}


researchers have pointed out that normalization is one of the potential reasons (García-Cascales \& Lamata 2012; Pamucar \& Ecer, 2020). In this regard, Senouci et al. (2016) worked on the possibilities to avoid or reduce the effect of RRP for TOPSIS method wherein they applied four normalization schemes. Therefore, for a justified reason for proceeding to examine whether the CODAS-LN framework suffers from any RRP. In this regard, two experiments are carried out in tune with the work of Mousavi-Nasab and SotoudehAnvari (2018). First, the best alternative is removed and the revised ordering is checked. Next, the worst alternative is eliminated and change in the relative ranking is observed. Table 8 points out the results of these two cases. It is evident from table 8 that RRP does not occur with the CODAS-LN approach. Further, for validation purpose it is necessary that the MCDM methods to satisfy the transitivity property (Roy et al., 2018; Sharma et al., 2018). Hence, it is examined whether the framework of CODAS-LN satisfies the transitivity property test as suggested in Wang and
Triantaphyllou (2008) and Triantaphyllou and Shu (2001). A non-optimal alternative such as M10 is replaced with another worse one such as M11 and the relative rankings are checked. Table 9 shows the finding which indicates that CODAS-LN follows the transitivity property.

\subsection{Sensitivity analysis}

Now the sensitivity analysis is carried out. Any MCDM framework is based on the goal to reduce the bias and ensure reliability of the solution (Pamučar et al., 2017; Mukhametzyanov \& Pamučar, 2018). Criteria weights contribute significantly in finding out the final ranking. Hence, changes in the criteria weights may affect the final solution of the MCDM framework. Therefore, a sensitivity analysis is required to be performed for checking the stability of the solution subject to variations in the criteria weights in a given situation (Pamučar \& Ćirović, 2015; Gharib, 2020). In this paper, the approach as suggested by Önüt et al. (2009) is followed which is based on exchange of criteria weights.

Table 8. Results of rank reversal test

\begin{tabular}{llllllll}
\hline Model & $\begin{array}{l}\text { Rank } \\
\text { (CODAS- } \\
\text { LN) }\end{array}$ & $\begin{array}{l}\text { Rank (without } \\
\text { best alternative) }\end{array}$ & $\begin{array}{l}\text { Rank (without the best } \\
\text { and worst alternative) }\end{array}$ & $\begin{array}{l}\text { Model } \\
\text { Rank } \\
\text { (CN) } \\
\text { LNS- }\end{array}$ & $\begin{array}{l}\text { Rank (without } \\
\text { best alternative ) }\end{array}$ & $\begin{array}{l}\text { Rank (without the } \\
\text { best and worst } \\
\text { alternative) }\end{array}$ \\
\hline M1 & 6 & 5 & 5 & M14 & 15 & 14 & 14 \\
M2 & 20 & 19 & 19 & M15 & 22 & 21 & 21 \\
M3 & 10 & 9 & 9 & M16 & 5 & 4 & 4 \\
M4 & 4 & 3 & 3 & M17 & 12 & 11 & 11 \\
M5 & 9 & 8 & 8 & M18 & 7 & 6 & 6 \\
M6 & 1 & & & M19 & 2 & 1 & 1 \\
M7 & 16 & 15 & 15 & M20 & 17 & 16 & 16 \\
M8 & 21 & 20 & 20 & M21 & 25 & 24 & 13 \\
M9 & 8 & 7 & M22 & 14 & 13 & 12 \\
M10 & 23 & 22 & M23 & 13 & 12 & 18 \\
M11 & 24 & 23 & 22 & M24 & 19 & 18 & 2 \\
M12 & 11 & 10 & 23 & M25 & 3 & 2 & \\
M13 & 18 & 17 & 10 & & & & 18 \\
\hline
\end{tabular}


Accordingly, the highest weight is exchanged with that of next three higher weights and three lowest weights subsequently. Table 10 depicts the experimental cases.

Table 11 shows the variations in relative rankings of the smartphones under different cases. It is observed from this sensitivity analysis that except few positional variations, the rankings remain consistent. This finding is supported by the correlation among the ranking results obtained under different situations as given in table 12 . Figure 1 pictorially represents the results of the sensitivity analysis which reveals the same fact as found in table 11 and 12 .

\section{CONCLUSION}

In this paper an extended version of the fundamental CODAS framework by using $\mathrm{LN}$ is proposed. $\mathrm{LN}$ is found quite rare in use in the literature but as suggested by Zavadskas and Turskis (2008), this scheme is useful when there is a significant variation among the criteria. This framework is applied for solving smartphone selection problem in Indian context. It is observed that buyers tend to incline on computational

Table 9. Results of transitivity test

\begin{tabular}{cccccc}
\hline Model & $\begin{array}{c}\text { Rank } \\
\text { (CODAS_LN) }\end{array}$ & $\begin{array}{c}\text { Rank } \\
\text { (Transitivity test) }\end{array}$ & Model & $\begin{array}{c}\text { Rank } \\
\text { (CODAS_LN) }\end{array}$ & $\begin{array}{c}\text { Rank } \\
\text { (Transitivity test) }\end{array}$ \\
\hline M1 & 6 & 6 & M14 & 15 & 15 \\
M2 & 20 & 20 & M15 & 22 & 22 \\
M3 & 10 & 10 & M16 & 5 & 5 \\
M4 & 4 & 4 & M17 & 12 & 12 \\
M5 & 9 & 9 & M18 & 7 & 7 \\
M6 & 1 & 1 & M19 & 2 & 2 \\
M7 & 16 & 16 & M20 & 17 & 17 \\
M8 & 21 & 21 & M21 & 25 & 25 \\
M9 & 8 & 8 & M22 & 14 & 14 \\
M10 & 23 & 24 & M23 & 13 & 13 \\
M11 & 24 & 23 & M24 & 19 & 19 \\
M12 & 11 & 11 & M25 & 3 & 3 \\
M13 & 18 & 18 & & & \\
\hline
\end{tabular}

Table 10. Exchange of criteria weight for sensitivity analysis

\begin{tabular}{lccccccccccc}
\hline Scenario & \multicolumn{10}{c}{ Criteria weights } \\
\cline { 2 - 12 } & C1 & C2 & C3 & C4 & C5 & C6 & C7 & C8 & C9 & C10 & C11 \\
\hline Original & 0.0243 & 0.1517 & 0.0873 & 0.0845 & 0.0529 & 0.1017 & 0.2244 & 0.1108 & 0.0329 & 0.0816 & 0.0480 \\
Case 1 & 0.2244 & 0.1517 & 0.0873 & 0.0845 & 0.0529 & 0.1017 & 0.0243 & 0.1108 & 0.0329 & 0.0816 & 0.0480 \\
Case 2 & 0.0243 & 0.2244 & 0.0873 & 0.0845 & 0.0529 & 0.1017 & 0.1517 & 0.1108 & 0.0329 & 0.0816 & 0.0480 \\
Case 3 & 0.0243 & 0.1517 & 0.0873 & 0.0845 & 0.0529 & 0.1017 & 0.1108 & 0.2244 & 0.0329 & 0.0816 & 0.0480 \\
Case 4 & 0.0243 & 0.1517 & 0.0873 & 0.0845 & 0.0529 & 0.2244 & 0.1017 & 0.1108 & 0.0329 & 0.0816 & 0.0480 \\
Case 5 & 0.0243 & 0.1517 & 0.0873 & 0.0845 & 0.0529 & 0.1017 & 0.0329 & 0.1108 & 0.2244 & 0.0816 & 0.0480 \\
Case 6 & 0.0243 & 0.1517 & 0.0873 & 0.0845 & 0.0529 & 0.1017 & 0.0480 & 0.1108 & 0.0329 & 0.0816 & 0.2244 \\
\hline
\end{tabular}


power of smartphones. The result obtained by using CODAS-LN shows considerably level of accuracy and stability. However, this study is limited to following scopes which invokes future research. First, given the nature of the logarithmic function, $\mathrm{LN}$ often causes distortion in the normalized values. More specifically, it is observed that if the performance values of the alternatives subject to a criterion are greater than 30 , the distortion becomes visible in the sense that the normalized values are very close to each other. This paper also suffers from the limitation as mentioned here. However, in a real-life problem like the present one the performance values may belong to any range. Hence, an effort can be made to find out the ways to deal with such situations when researchers use LN for multi-criteria based decision analysis. Second, in case of CODAS framework, the threshold parameter $\tau$ plays an important role. Therefore, one future study may consider variations in $\tau$ and check the results under different normalization schemes. Third, the impact of LN can be further tested by applying the CODAS method in uncertain environment using fuzzy or grey numbers. Fourth, in this paper a general sensitivity analysis is performed. One may attempt to carry out a statistical sensitivity analysis. Fifth, in CODAS method a combination of two different distance measures is used. One future study may examine the impact of changes in distance measures on the relative rankings while using $\mathrm{LN}$. Sixth, the results obtained by using objective information may be further contrasted with subjective reviews of the users as obtained through natural language processing (NLP). Seventh, the moderation effect of socio-economic factors may also be considered on the purchase intention of the smartphones while using the composite ranking scores as inputs. Nevertheless, it is assumed that this limitation may not undermine the usefulness

Table 11. Ranking results under different scenarios (sensitivity analysis)

\begin{tabular}{|c|c|c|c|c|c|c|c|}
\hline \multirow{2}{*}{ Model } & \multirow{2}{*}{$\begin{array}{c}\text { Rank } \\
\text { (original) }\end{array}$} & \multicolumn{6}{|c|}{ Scenarios (Sensitivity Analysis) } \\
\hline & & Rank (Case 1) & Rank (Case 2) & Rank (Case 3) & Rank (Case 4) & Rank (Case 5) & Rank (Case 6) \\
\hline M1 & 6 & 8 & 6 & 7 & 7 & 6 & 7 \\
\hline M2 & 20 & 19 & 19 & 20 & 22 & 18 & 20 \\
\hline M3 & 10 & 15 & 12 & 12 & 15 & 12 & 13 \\
\hline M4 & 4 & 5 & 5 & 5 & 6 & 7 & 5 \\
\hline M5 & 9 & 11 & 11 & 10 & 11 & 11 & 11 \\
\hline M6 & 1 & 3 & 2 & 2 & 1 & 3 & 2 \\
\hline M7 & 16 & 16 & 17 & 16 & 17 & 14 & 16 \\
\hline M8 & 21 & 21 & 21 & 21 & 20 & 21 & 21 \\
\hline M9 & 8 & 10 & 8 & 9 & 10 & 10 & 10 \\
\hline M10 & 23 & 22 & 23 & 23 & 23 & 22 & 23 \\
\hline M11 & 24 & 24 & 24 & 24 & 24 & 23 & 24 \\
\hline M12 & 11 & 14 & 10 & 13 & 12 & 15 & 15 \\
\hline M13 & 18 & 18 & 18 & 18 & 19 & 20 & 18 \\
\hline M14 & 15 & 13 & 16 & 15 & 16 & 16 & 14 \\
\hline M15 & 22 & 23 & 22 & 22 & 21 & 24 & 22 \\
\hline M16 & 5 & 6 & 7 & 6 & 8 & 5 & 6 \\
\hline M17 & 12 & 1 & 1 & 1 & 3 & 1 & 1 \\
\hline M18 & 7 & 9 & 9 & 8 & 9 & 9 & 9 \\
\hline M19 & 2 & 2 & 3 & 3 & 2 & 2 & 3 \\
\hline M20 & 17 & 17 & 15 & 17 & 18 & 17 & 17 \\
\hline M21 & 25 & 25 & 25 & 25 & 25 & 25 & 25 \\
\hline M22 & 14 & 12 & 14 & 14 & 14 & 13 & 12 \\
\hline M23 & 13 & 7 & 13 & 11 & 4 & 8 & 8 \\
\hline M24 & 19 & 20 & 20 & 19 & 13 & 19 & 19 \\
\hline M25 & 3 & 4 & 4 & 4 & 5 & 4 & 4 \\
\hline
\end{tabular}


Table 12. Consistency test II

\begin{tabular}{|c|c|c|c|c|c|c|c|c|}
\hline & & $\begin{array}{l}\text { Original__ } \\
\text { Rank }\end{array}$ & $\begin{array}{l}\text { Rank_ } \\
\text { Case1 }\end{array}$ & $\begin{array}{l}\text { Rank_ } \\
\text { Case } 2\end{array}$ & $\begin{array}{l}\text { Rank_ } \\
\text { Case3 }\end{array}$ & $\begin{array}{l}\text { Rank_ } \\
\text { Case } 4\end{array}$ & $\begin{array}{l}\text { Rank_ } \\
\text { Case } 5\end{array}$ & $\begin{array}{l}\text { Rank } \\
\text { Case6 }\end{array}$ \\
\hline \multirow{7}{*}{ Kendall's tau } & Original_Rank & 1 & & & & & & \\
\hline & Rank_Case1 & $.833 * *$ & 1 & & & & & \\
\hline & Rank_Case2 & $.880 * *$ & .887 ** & 1 & & & & \\
\hline & Rank_Case3 & $.913 * *$ & $.920 * *$ & $.940 * *$ & 1 & & & \\
\hline & Rank_Case4 & $.807 * *$ & $.867 * *$ & $.833 * *$ & $.867 * *$ & 1 & & \\
\hline & Rank_Case5 & $.820 * *$ & $.920 * *$ & $.860 * *$ & $.907 * *$ & $.827 * *$ & 1 & \\
\hline & Rank_Case6 & $.873 * *$ & $.960 * *$ & $.900 * *$ & $.960 * *$ & $.880 * *$ & $.920 * *$ & 1 \\
\hline \multirow{7}{*}{ Spearman's rho } & Original_Rank & 1 & & & & & & \\
\hline & Rank_Case1 & $.913 * *$ & 1 & & & & & \\
\hline & Rank_Case2 & $.942 * *$ & $.965^{* *}$ & 1 & & & & \\
\hline & Rank_Case3 & $.945^{* *}$ & $.983 * *$ & $.990 * *$ & 1 & & & \\
\hline & Rank_Case4 & $.898 * *$ & $.958 * *$ & $.932 * *$ & $.954 * *$ & 1 & & \\
\hline & Rank_Case5 & $.918 * *$ & $.984 * *$ & $.965 * *$ & $.983 * *$ & $.950 * *$ & 1 & \\
\hline & Rank_Case6 & $.925^{* *}$ & $.995 * *$ & $.972 * *$ & $.992 * *$ & $.964 * *$ & $.988 * *$ & 1 \\
\hline
\end{tabular}

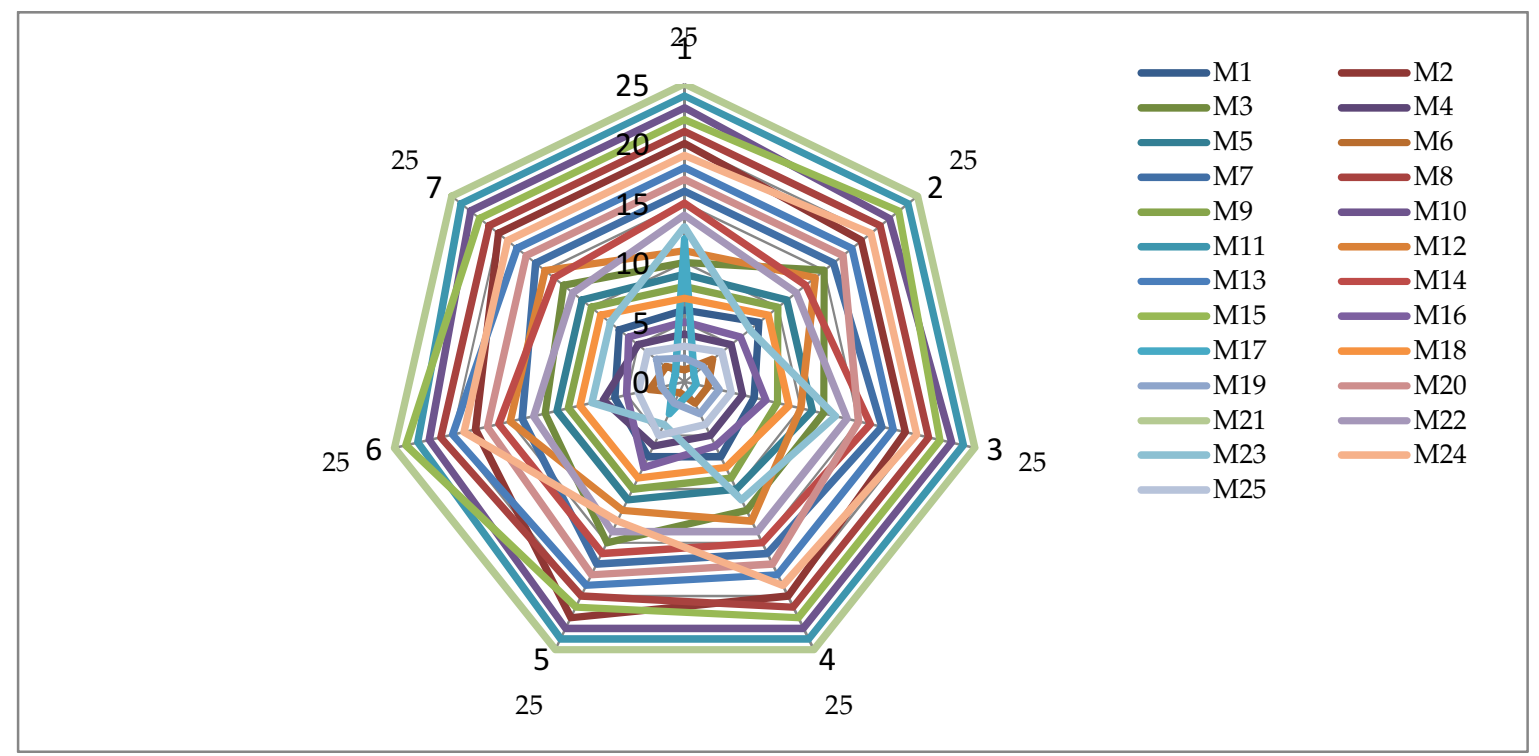

Figure 1. Results of sensitivity analysis (graphical representation)

of this paper as this is a first-hand attempt to solve a real-life problem by using the CODAS-LN framework. The methodology as expressed here and the findings obtained shall be useful for the decision-makers who wish to select a high-tech products like smartphone. This extended framework is equally applicable in other social science and engineering problems which will be of interest of the researchers and practitioners involved in solving complex selection problems among the available choices for product design and delivery, process designing and many other issues.

\section{Conflict of Interest}

The authors declare no conflict of interest.

\section{Acknowledgement}

The authors would like to express their 
sincere gratitude to all anonymous reviewers whose valuable comments have helped in developing and improving the quality of this paper.

\section{Funding}

The authors received no external funding for carrying out this research.

\section{References}

Aggarwal, A., Choudhary, C., \& Mehrotra, D. (2018). Evaluation of smartphones in Indian market using EDAS. Procedia computer science, 132, 236-243.

Badi, I., Abdulshahed, A.M., \& Shetwan, A. (2018a). A case study of supplier selection for a steelmaking company in Libya by using the Combinative Distancebased ASsessment (CODAS) model. Decision Making: Applications in Management and Engineering, 1 (1), 1-12.

Badi, I., Ballem, M., \& Shetwan, A. (2018b). Site selection of desalination plant in Libya by using combinative distancebased assessment (CODAS) method. International Journal for Quality Research, 12 (3), 609-624.

Biswas, S., Bandyopadhyay, G., Guha, B., \& Bhattacharjee, M. (2019). An ensemble approach for portfolio selection in a multi-criteria decision making framework. Decision Making: Applications in Management and Engineering, 2 (2), 138158.

Biswas, S., \& Pamucar, D. (2020). Facility Location Selection for B-Schools in Indian Context: A Multi-Criteria Group Decision Based Analysis. Axioms, 9(3), 77.

Bolturk, E., \& Kahraman, C. (2018). Interval-valued intuitionistic fuzzy CODAS method and its application to wave energy facility location selection problem. Journal of Intelligent \& Fuzzy Systems, 35 (4), 4865-4877.

Boltürk, E., \& Karaşan, A. (2018). Interval valued neutrosophic CODAS method for renewable energy selection. In Liu, J., Lu, J., Xu, Y., Martinez, L., Kerre, E.E. (Eds), Data Science and Knowledge Engineering for Sensing Decision Support, 1026-1033.

Büyüközkan, G., \& Güleryüz, S. (2016). Multi criteria group decision making approach for smart phone selection using intuitionistic fuzzy TOPSIS. International Journal of Computational Intelligence Systems, 9(4), 709-725.

Çelen, A. (2014). Comparative analysis of normalization procedures in TOPSIS method: with an application to Turkish deposit banking market. Informatica, 25 (2), 185-208.

Changyong, F.E.N.G., Hongyue, W.A.N.G., Naiji, L.U., Tian, C.H.E.N., Hua, H.E., \& Ying, L.U. (2014). Logtransformation and its implications for data analysis. Shanghai archives of psychiatry, 26 (2), 105-109.

Chatterjee, P., \& Chakraborty, S. (2014). Investigating the Effect of Normalization Norms in Flexible Manufacturing Sytem Selection Using Multi-Criteria DecisionMaking Methods. Journal of Engineering Science \& Technology Review, 7 (3), 141150.

Chatterjee, P., \& Stevic, Z. (2019). A twophase fuzzy AHP - fuzzy TOPSIS model for supplier evaluation in manufacturing environment. Operational Research in Engineering Sciences: Theory and Applications, 2 (1), 72-90.

de Farias Aires, R.F., \& Ferreira, L. (2019). A new approach to avoid rank 


\title{
ОКВИР КОМБИНОВАНЕ ПРОЦЕНЕ ЗАСНОВАНЕ НА УДАЉЕНОСТИ (СОDАS) КОЈИ КОРИСТИ ЛОГАРИТАМСКУ НОРМАЛИЗАЦИЈУ ЗА ВИШЕКРИТЕРИЈУМСКО ОДЛУЧИВАЊЕ
}

\author{
Sanjib Biswas, Dragan Pamucar
}

\section{Извод}

Сврха овог рада је да представи проширени оквир за процену засновану на комбинованој удаљености (CODAS) користећи шему логаритамске нормализације (ЛН). ЛН је користан у ситуацијама када се вредности критеријума значајно разликују. Овај оквир се користи за поређење популарних паметних телефона у Индији засновано на перформансама. Резултати добијени из ове проширене верзије „CODAS“ методе (CODAS-LN) показују доследност са оном који су добијени коришћењем неких других постојећих више-критеријумских приступа одлучивања (MCDM). Анализа осетљивости показује значајну стабилност резултата. Даље, примећено је да се код „CODAS-LN“ не јавља феномен преокрета ранга и следи својство транзитивности. Налази студије случаја указују на то да се паметни телефони са већим рачунским способностима и карактеристикама сврставају у горње нивое.

Кључне речи: CODAS метода, логаритамска нормализација, рангирање паметних телефона, анализа осетљивости

reversal cases in the TOPSIS method. Computers \& Industrial Engineering, 132, 84-97.

Dehghan-Manshadi, B., Mahmudi, H., Abedian, A., \& Mahmudi, R. (2007). A novel method for materials selection in mechanical design: combination of nonlinear normalization and a modified digital logic method. Materials \& design, 28 (1), 815.

Despic, D., Bojović, N., Kilibarda, M. \& Kapetanović, M. (2019). Assessment of efficiency of military transport units using the DEA and SFA methods. Military Technical Courier, 67 (1), 68-92.

Eftekhary, M., Gholami, P., Safari, S., \& Shojaee, M. (2012). Ranking normalization methods for improving the accuracy of SVM algorithm by DEA method. Modern applied science, 6 (10), 26-36.

García-Cascales, M.S., \& Lamata, M.T.
(2012). On rank reversal and TOPSIS method. Mathematical and Computer Modelling, 56(5-6), 123-132.

Gharib, M.R. (2020). Comparison of robust optimal QFT controller with TFC and MFC controller in a multi-input multi-output system. Reports in Mechanical Engineering, 1(1), 151-161.

Ghorabaee, M. K., Amiri, M., Zavadskas, E. K., Hooshmand, R., \& Antuchevičienè, J. (2017). Fuzzy extension of the CODAS method for multi-criteria market segment evaluation. Journal of Business Economics and Management, 18(1), 1-19.

Ghorabaee, M.K., Zavadskas, E.K., Olfat, L., \& Turskis, Z. (2015). Multicriteria inventory classification using a new method of evaluation based on distance from average solution (EDAS). Informatica, 26 (3), 435-451.

Ghorabaee, M. K., Zavadskas, E. K., 
Turskis, Z., \& Antucheviciene, J. (2016). A new combinative distance-based assessment (CODAS) method for multi-criteria decision-making. Economic Computation \& Economic Cybernetics Studies \& Research, 50 (3), 25-41.

Ghosh, I., \& Biswas, S. (2016). A comparative analysis of multi-criteria decision models for ERP package selection for improving supply chain performance. Asia-Pacific Journal of Management Research and Innovation, 12(3-4), 250-270.

Gupta, S., Bandyopadhyay, G., Bhattacharjee, M., \& Biswas, S. (2019). Portfolio Selection using DEA-COPRAS at Risk-Return Interface Based on NSE (India). International Journal of Innovative Technology and Exploring Engineering (IJITEE), 8 (10), 4078-4086.

Hassanpour, M., \& Pamucar, D. (2019). Evaluation of Iranian household appliance industries using MCDM models. Operational Research in Engineering Sciences: Theory and Applications, 2 (3), 125.

Hu, S.K., Lu, M.T., \& Tzeng, G.H. (2014). Exploring smart phone improvements based on a hybrid MCDM model. Expert Systems with Applications, 41 (9), 4401-4413.

Huszak, A., \& Imre, S. (2010, May). Eliminating rank reversal phenomenon in GRA-based network selection method. Proceedings of IEEE International Conference on Communications, ICC 2010, Cape Town, South Africa, 1-6.

Hwang, C.L., \& Yoon, K. (1981). Methods for multiple attribute decision making. In Multiple attribute decision making. Springer, Berlin, Heidelberg. 58191.

Ijadi Maghsoodi, A., Ijadi Maghsoodi, A., Poursoltan, P., Antucheviciene, J., \&
Turskis, Z. (2019). Dam construction material selection by implementing the integrated SWARA-CODAS approach with target-based attributes. Archives of Civil and Mechanical Engineering, 19, 11941210.

Irvanizam, I., Marzuki, M., Patria, I., \& Abubakar, R. (2018). An Application for Smartphone Preference Using TODIM Decision Making Method2018 International Conference on Electrical Engineering and Informatics (ICELTICs), 122-126.

Işıklar, G., \& Büyüközkan, G. (2007). Using a multi-criteria decision making approach to evaluate mobile phone alternatives. Computer Standards \& Interfaces, 29 (2), 265-274.

Jahan, A., \& Edwards, K. L. (2015). A state-of-the-art survey on the influence of normalization techniques in ranking: Improving the materials selection process in engineering design. Materials \& Design (1980-2015), 65, 335-342.

Jassbi, J.J., Ribeiro, R.A., \& Varela, L.R. (2014). Dynamic MCDM with future knowledge for supplier selection. Journal of Decision Systems, 23 (3), 232-248.

Karmakar, P., Dutta, P., \& Biswas, S. (2018). Assessment of mutual fund performance using distance based multicriteria decision making techniques-An Indian perspective. Research Bulletin, 44 (1), 17-38.

Kim, J., Lee, H., \& Lee, J. (2020). Smartphone preferences and brand loyalty: A discrete choice model reflecting the reference point and peer effect. Journal of Retailing and Consumer Services, 52, 101907.

Kong, F., Wei, W., \& Gong, J.H. (2016). Rank reversal and rank preservation in ANP method. Journal of Discrete Mathematical Sciences and Cryptography, 19 (3), 821-836. 
Kosareva, N., Krylovas, A., \& Zavadskas, E.K. (2018). Statistical analysis of MCDM data normalization methods using Monte Carlo approach. The case of ternary estimates matrix. Economic Computation and Economic Cybernetics Studies and Research, 52 (4), 159-175.

Laha, S., \& Biswas, S. (2019). A hybrid unsupervised learning and multi-criteria decision making approach for performance evaluation of Indian banks. Accounting, 5 (4), 169-184.

Li, X., Wang, K., Liu, L., Xin, J., Yang, H., \& Gao, C. (2011). Application of the entropy weight and TOPSIS method in safety evaluation of coal mines. Procedia Engineering, 26, 2085-2091.

Macharis, C., Springael, J., De Brucker, K., \& Verbeke, A. (2004). PROMETHEE and AHP: The design of operational synergies in multicriteria analysis.: Strengthening PROMETHEE with ideas of AHP. European Journal of Operational Research, 153 (2), 307-317.

Mathew, M., Sahu, S., \& Upadhyay, A.K. (2017). Effect of normalization techniques in robot selection using weighted aggregated sum product assessment. International Journal of Innovative Research and Advanced Studies, 4 (2), 59-63.

Mousavi-Nasab, S. H., \& SotoudehAnvari, A. (2018). A new multi-criteria decision making approach for sustainable material selection problem: A critical study on rank reversal problem. Journal of Cleaner Production, 182, 466-484.

Mukhametzyanov, I., \& Pamucar, D. (2018). A sensitivity analysis in MCDM problems: A statistical approach. Decision making: applications in management and engineering, 1 (2), 51-80.

Önüt, S., Kara, S.S., \& Işik, E. (2009). Long term supplier selection using a combined fuzzy MCDM approach: A case study for a telecommunication company. Expert systems with applications, 36 (2), 3887-3895.

Pamučar, D.S., Božanić, D., \& Ranđelović, A. (2017). Multi-criteria decision making: An example of sensitivity analysis. Serbian journal of management, 12 (1), 1-27.

Pamučar, D., \& Ćirović, G. (2015). The selection of transport and handling resources in logistics centers using Multi-Attributive Border Approximation area Comparison (MABAC). Expert systems with applications, 42 (6), 3016-3028.

Pamucar, D., Ecer, F. (2020). Prioritizing the weights of the evaluation criteria under fuzziness: The fuzzy full consistency method - FUCOM-F. Facta Universitatis, series: Mechanical Engineering, 18 (3), 419 - 437.

Pamucar, D.S. \& Savin, L.M. (2020). Multiple-criteria model for optimal off-road vehicle selection for passenger transportation: BWM-COPRAS model. Military Technical Courier, 68 (1), 28-64.

Panchal, D., Chatterjee, P., Shukla, R. K., Choudhury, T., \& Tamosaitiene, J. (2017). Integrated Fuzzy AHP-Codas Framework for Maintenance Decision in Urea Fertilizer Industry. Economic Computation \& Economic Cybernetics Studies \& Research, 51(3), 179-196.

Pavličić, D. (2001). Normalization affects the results of MADM methods. Yugoslav journal of operations research, 11 (2), 251265.

Precup, R.-E., Preitl , S., Petriu, E., Bojan-Dragos, C.-A., Szedlak-Stinean, A.I., Roman, R.-C., \& Hedrea, E.-L. (2020). Model-Based Fuzzy Control Results for Networked Control Systems. Reports in Mechanical Engineering, 1 (1), 10-25.

Rani, P., Mishra, A.R., \& Ansari, M.D. 
(2019). Analysis of Smartphone Selection Problem under Interval-valued Intuitionistic Fuzzy ARAS and TOPSIS Methods. 2019 Fifth International Conference on Image Information Processing (ICIIP), 509-514.

Ren, J. (2018). Sustainability prioritization of energy storage technologies for promoting the development of renewable energy: A novel intuitionistic fuzzy combinative distance-based assessment approach. Renewable energy, 121, 666-676.

Roy, J., Chatterjee, K., Bandyopadhyay, A., \& Kar, S. (2018). Evaluation and selection of medical tourism sites: A rough analytic hierarchy process based multi-attributive border approximation area comparison approach. Expert Systems, 35(1), e12232.

Saqlain, M., Jafar, M. N., \& Riaz, M. (2020). A New Approach of Neutrosophic Soft Set with Generalized Fuzzy TOPSIS in Application of Smart Phone Selection. Neutrosophic Sets and Systems, 32 (1), 307316.

Sarraf, A.Z., Mohaghar, A., \& Bazargani, H. (2013). Developing TOPSIS method using statistical normalization for selecting Knowledge management strategies. Journal of Industrial Engineering and Management, 6 (4), 860-875.

Seker, S. (2020). A novel interval-valued intuitionistic trapezoidal fuzzy combinative distance-based assessment (CODAS) method. Soft Computing, 24 (3), 2287-2300.

Senouci, M.A., Mushtaq, M.S., Hoceini, S., \& Mellouk, A. (2016). TOPSIS-based dynamic approach for mobile network interface selection. Computer Networks, 107, 304-314.

Shannon, C.E. (1948). A mathematical theory of communication. Bell Systems Technical Journal, 27 (3), 379-423.

Sharma, H.K., Roy, J., Kar, S., \&
Prentkovskis, O. (2018). Multi criteria evaluation framework for prioritizing indian railway stations using modified rough ahpmabac method. Transport and telecommunication journal, 19 (2), 113-127.

Soltanifar, M., \& Shahghobadi, S. (2014). Survey on rank preservation and rank reversal in data envelopment analysis. Knowledge-Based Systems, 60, 10-19.

Triantaphyllou, E., \& Shu, B. (2001). On the maximum number of feasible ranking sequences in multi-criteria decision making problems. European Journal of Operational Research, 130 (3), 665-678.

Tuş, A., \& Adal1, E.A. (2018). Personnel assessment with CODAS and PSI methods. Alphanumeric Journal, 6 (2), 243-256.

Vafaei, N., Ribeiro, R.A., \& CamarinhaMatos, L.M. (2018). Data normalisation techniques in decision making: case study with TOPSIS method. International journal of information and decision sciences, 10 (1), 19-38.

Wang, X., \& Triantaphyllou, E. (2008). Ranking irregularities when evaluating alternatives by using some ELECTRE methods. Omega, 36 (1), 45-63.

Wang, Y.M., \& Luo, Y. (2009). On rank reversal in decision analysis. Mathematical and Computer Modelling, 49 (5-6), 12211229.

Yeni, F.B., \& Özçelik, G. (2019). Interval-valued Atanassov intuitionistic Fuzzy CODAS method for multi criteria group decision making problems. Group Decision and Negotiation, 28 (2), 433-452.

Yildiz, A., \& Ergul, E.U. (2015). A twophased multi-criteria decision-making approach for selecting the best smartphone. South African Journal of Industrial Engineering, 26 (3), 194-215.

Zavadskas, E.K., \& Turskis, Z. (2008). A new logarithmic normalization method in 
games theory. Informatica, 19 (2), 303-314.

Zavadskas, E.K., \& Turskis, Z. (2011).

Multiple criteria decision making (MCDM) methods in economics: an overview. Technological and economic development of economy, 17 (2), 397-427.

Zavadskas, E.K., Zakarevicius, A., \& Antucheviciene, J. (2006). Evaluation of ranking accuracy in multi-criteria decisions. Informatica, 17 (4), 601-618.

Zhou, J., Li, K.W., Baležentis, T., \& Streimikiene, D. (2020). Pythagorean fuzzy combinative distance-based assessment with pure linguistic information and its application to financial strategies of multinational companies. Economic ResearchEkonomska Istraživanja, 33 (1), 974-998.

Zolfani, S.H., Yazdani, M., Pamucar, D., $\&$ Zarate, P. (2020). A VIKOR and TOPSIS focused reanalysis of the MADM methods based on logarithmic normalization. Facta universitatis series: Mechanical Engineering, 18 (3), 341-355.

Zou, Z.H., Yi, Y., \& Sun, J.N. (2006). Entropy method for determination of weight of evaluating indicators in fuzzy synthetic evaluation for water quality assessment. Journal of Environmental sciences, 18 (5), 1020-1023. 